\title{
Continuity of Midwifery Care Implementation to Reduce Stunting
}

\author{
Nurfatimah Nurfatimah $^{1 *} \mathbb{D}$, Kadar Ramadhan $^{1} \mathbb{D}$, Christina Entoh $^{1} \mathbb{D}$, Lisda Widianti Longgupa ${ }^{1}$, Fahmi Hafid ${ }^{2} \mathbb{D}$ \\ Department of Midwifery, Poltekkes Kemenkes Palu, Palu, Indonesia; ${ }^{2}$ Department of Nutrition, Poltekkes Kemenkes Palu, \\ Palu, Indonesia
}

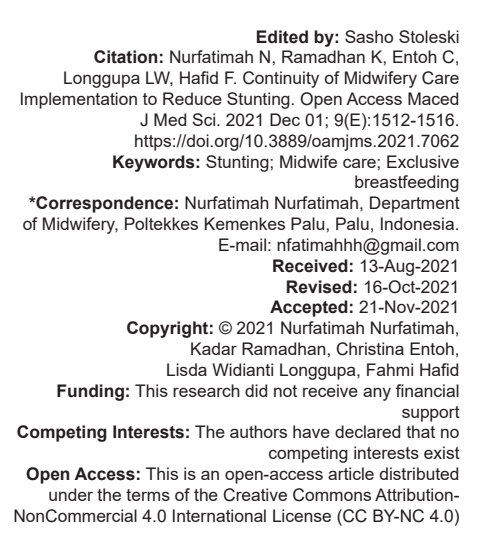

Introduction

Stunting is a condition of failure to thrive in children under five due to chronic malnutrition, especially in the first 1000 days of life. Stunting affects brain growth and development. Stunting children also have a higher risk of suffering from chronic diseases in adulthood. Stunting and malnutrition are estimated to contribute to a $2-3 \%$ reduction in gross domestic product each year [1].

Stunting in childhood is one of the most significant barriers to human development [2]. Globally, around 150.8 million or around $22.2 \%$ of children under the age of five are stunted. In addition, 50.5 million (7.5\%) under-fives also experienced wasting, and 38.3 million $(5.6 \%)$ were underweight [3], [4]. The Basic Health Research (2018) results show that $30.8 \%$ of infants under 5 years of age (toddlers) suffer from stunting. This means that as many as 7 million children under five in Indonesia today, who are the nation's generation, are threatened with a lack of competitiveness in their future lives. The decline in the stunting rate in Indonesia over the past 10 years has not shown any significant changes [5].

The prevalence of stunting in the Central Sulawesi is still high. According to the nutrition status monitoring data, in 2015 , it was $35.3 \%$ down to $32 \%$ in 2016 but again rose to $36.1 \%$ in 2017 . This figure is still far above the WHO target, below 20\% [6], [7]. In Poso District, the prevalence of stunting in 2013 was $39.4 \%$ and decreased to $26.2 \%$ in 2018 . This considerable decline places Poso as the third lowest stunting district after Palu City and Kab. Tojo Una-Una [8], [9].

Stunting can be prevented, starting with the role of parents. Prevention measures start from the first 1000 days of life, 8 months in the womb and 2 years after birth. Through public health services in all regions, the Ministry of Health (Kemkes) encourages the fulfillment of exclusive breastfeeding or babies only consume breast milk for 6 months and continued breastfeeding with complementary foods for 2 years for toddlers [10], [11].

Several causes, as described above, have contributed to the high prevalence of stunting in Indonesia, and therefore, a comprehensive intervention plan is needed to reduce the prevalence of stunting in Indonesia [11]. Efforts to improve the continuity and quality of mothers and children are carried out with an approach through comprehensive midwifery care. Comprehensive midwifery care means services provided in the life cycle starting from pregnancy, childbirth, postpartum, infant, and family planning. If the 
intervention approach of comprehensive midwifery care is implemented, it will have a significant impact on the survival and quality of life of mothers and children [12].

The prevalence of stunting in the Mapane Health Center area is still high, above $30 \%$, and this is a public health problem. One way to overcome these problems is to increase the participation of midwives, through the provision of comprehensive midwifery care. Comprehensive midwifery care can optimize the detection of high-risk maternal and neonatal. This effort can involve various sectors to carry out assistance to pregnant women as a promotive and preventive effort starting from when the pregnant woman is found until the woman in the postpartum period ends through counseling, information, and education [13], [14]. Comprehensive midwifery care is an examination carried out in full, starting from midwifery care for pregnancy, midwifery care for childbirth, midwifery care during the puerperium, and midwifery care for newborns and family planning care (Kemenkes RI, 2016). Comprehensive midwifery care can be one of the specific intervention efforts aimed at children in the first 1000 days of life and contribute to a $30 \%$ reduction in stunting. This intervention is also shortterm, where the results can be recorded in a relatively short time so that the implementation of comprehensive midwifery care is expected to prevent stunting in the working area of the Mapane Health Center.

\section{Methods}

This study was a longitudinal study with a cohort approach carried out in April-November 2020. The population in this study were all third-trimester pregnant women in the Mapane Health Center work area. The sample in this study was all pregnant women in the Mapane Health Center area (total sampling), which amounted to 32 people as the intervention group, while for the control group was 32 third trimester pregnant women in the Mapane Health Center work area. In the intervention group, midwifery care was carried out by visiting 4 times, namely, 2 times ANC, 1 time INC, and 1 time PNC. Then, monitor the growth of the baby when the child was 6 months old. Due to the COVID-19 pandemic, the implementation was also carried out online.

The instrument used for data collection is a healthy family questionnaire through the ODK collect android-based application, which can be accessed through https://ee.kobotoolbox.org/x/ $\mathrm{x} 2$ WChViy. The dependent variable in this study was the incidence of stunting. The independent variables were age, education, work parity, gender of the child, implementation of early initiation of breastfeeding, breastfeeding, chronic energy deficiency, the incidence of hypertension in pregnancy, and the type of delivery.
The analysis used was descriptive, namely, the proportion and mean difference. The analysis was performed using the WHO Anthro version 3.2.2 and STATA 15.1. The WHO Anthro was used to determine the $z$ value of each nutritional indicator then the data were exported to STATA for further analysis. The hypothesis test was used as Chi-square.

This research has passed an ethical review and obtained ethical clearance from the Health Research Ethics Commission of the Polytechnic of the Ministry of Health Palu Number: LB.01.01/KE/0014.1/IV/2020.

\section{Results}

Table 1 shows no difference in the proportions of age, education, occupation, parity, child sex, early breastfeeding initiation, breastfeeding, hypertension in pregnancy, type of delivery, place of delivery, and the incidence of stunting at 0 months between the control and intervention groups. There was a difference in the proportion of stunting between the control and intervention groups at the age of 6 months.

Table 1: Characteristics of respondents

\begin{tabular}{|c|c|c|c|c|c|}
\hline \multirow[t]{3}{*}{ Variable } & \multicolumn{4}{|c|}{ Groups } & \multirow[t]{3}{*}{$p$-value } \\
\hline & \multicolumn{2}{|c|}{ Control } & \multicolumn{2}{|c|}{ Intervention } & \\
\hline & $\mathrm{n}$ & $\%$ & $\mathrm{n}$ & $\%$ & \\
\hline \multicolumn{6}{|l|}{ Age } \\
\hline$<20$ years & 5 & 15.6 & 4 & 12.5 & \multirow[t]{3}{*}{0.328} \\
\hline $20-35$ years & 23 & 71.9 & 27 & 84.4 & \\
\hline$>35$ years & 4 & 12.5 & 1 & 3.1 & \\
\hline \multicolumn{6}{|l|}{ Education } \\
\hline Junior High School & 4 & 12.5 & 4 & 12.5 & \multirow[t]{3}{*}{1.000} \\
\hline Senior High School & 27 & 84.4 & 27 & 84.4 & \\
\hline University & 1 & 3.1 & 1 & 3.1 & \\
\hline \multicolumn{6}{|l|}{ Job } \\
\hline Working & 3 & 9.4 & 3 & 9.4 & \multirow[t]{2}{*}{1.000} \\
\hline Not working & 29 & 90.6 & 29 & 90.6 & \\
\hline \multicolumn{6}{|l|}{ Parity } \\
\hline Primipara & 9 & 28.1 & 7 & 21.9 & \multirow[t]{3}{*}{0.739} \\
\hline Multipara & 22 & 68.8 & 23 & 71.9 & \\
\hline Grandepara & 1 & 3.1 & 2 & 6.3 & \\
\hline \multicolumn{6}{|l|}{ Child gender } \\
\hline Male & 14 & 43.8 & 18 & 56.3 & \multirow[t]{2}{*}{0.453} \\
\hline Female & 18 & 56.3 & 14 & 43.8 & \\
\hline \multicolumn{6}{|c|}{ Early initiation of breastfeeding } \\
\hline No & 11 & 34.4 & 12 & 37.5 & \multirow[t]{2}{*}{1.000} \\
\hline Yes & 21 & 65.6 & 20 & 62.5 & \\
\hline \multicolumn{6}{|l|}{ Breastfeeding } \\
\hline No & 18 & 56.3 & 11 & 34.4 & \multirow[t]{2}{*}{0.131} \\
\hline Yes & 14 & 43.8 & 21 & 65.6 & \\
\hline \multicolumn{6}{|l|}{ Chronic energy lack } \\
\hline Yes & 5 & 15.6 & 7 & 21.9 & \multirow[t]{2}{*}{0.750} \\
\hline No & 27 & 84.4 & 25 & 78.1 & \\
\hline \multicolumn{6}{|c|}{ Hypertension in pregnancy } \\
\hline Yes & 1 & 3.1 & 2 & 6.3 & \multirow[t]{2}{*}{1.000} \\
\hline No & 31 & 96.9 & 30 & 93.8 & \\
\hline Type of delivery & & & & & \\
\hline SC & 10 & 31.3 & 9 & 28.1 & 1.000 \\
\hline Normal & 22 & 68.6 & 23 & 71.9 & \\
\hline Place of birth & & & & & \\
\hline Hospital & 13 & 40.6 & 12 & 37.5 & 1.000 \\
\hline Public health center & 19 & 59.4 & 20 & 62.5 & \\
\hline Stunting at 0 months & & & & & \\
\hline Yes & 2 & 6.3 & 2 & 6.3 & 1.000 \\
\hline No & 30 & 93.8 & 30 & 93.8 & \\
\hline Stunting at 6 months & & & & & \\
\hline Yes & 9 & 28.1 & 1 & 3.1 & 0.013 \\
\hline No & 23 & 71.9 & 31 & 96.9 & \\
\hline${ }^{*} \mathrm{p}$-value & & & & & \\
\hline
\end{tabular}

Table 2 shows that most mothers aged $>35$ years, junior high school education, working mothers, grande-multipara, and male gender, did not do early 
breastfeeding initiation and exclusive breastfeeding. Furthermore, they experienced chronic energy deficiency and hypertension in pregnancy gave birth in the hospital, and experiencing stunting at the age of 0 months will experience stunting at the age of 6 months.

Table 2: Bivariate analysis of stunting

\begin{tabular}{|c|c|c|c|c|c|}
\hline \multirow[t]{3}{*}{ Variable } & \multicolumn{4}{|c|}{ Stunting } & \multirow[t]{3}{*}{$p$-value } \\
\hline & \multicolumn{2}{|l|}{ Yes } & \multicolumn{2}{|l|}{ No } & \\
\hline & $\mathrm{n}(10)$ & $\%(15.6)$ & $\mathrm{n}(54)$ & $\%(84.4)$ & \\
\hline \multicolumn{6}{|l|}{ Age } \\
\hline$<20$ years & 1 & 11.1 & 8 & 88.9 & \multirow[t]{3}{*}{0.017} \\
\hline $20-35$ years & 6 & 12.0 & 44 & 88.0 & \\
\hline$>35$ years & 3 & 60.0 & 2 & 40.0 & \\
\hline \multicolumn{6}{|l|}{ Education } \\
\hline Junior High School & 2 & 25.0 & 6 & 75.0 & \multirow[t]{3}{*}{0.628} \\
\hline Senior High School & 8 & 14.8 & 46 & 85.2 & \\
\hline University & 0 & 0.0 & 2 & 100.0 & \\
\hline \multicolumn{6}{|l|}{ Job } \\
\hline Working & 1 & 16.7 & 5 & 83.3 & \multirow[t]{2}{*}{1.000} \\
\hline Not working & 9 & 15.5 & 49 & 84.5 & \\
\hline \multicolumn{6}{|l|}{ Parity } \\
\hline Primipara & 2 & 12.5 & 14 & 87.5 & \multirow[t]{3}{*}{0.660} \\
\hline Multipara & 7 & 15.6 & 38 & 84.4 & \\
\hline Grandepara & 1 & 33.3 & 2 & 66.7 & \\
\hline \multicolumn{6}{|l|}{ Child gender } \\
\hline Male & 6 & 18.8 & 26 & 81.3 & \multirow[t]{2}{*}{0.731} \\
\hline Female & 4 & 12.5 & 28 & 87.5 & \\
\hline \multicolumn{6}{|c|}{ Early initiation of breastfeeding } \\
\hline No & 5 & 21.7 & 18 & 78.3 & \multirow[t]{2}{*}{0.474} \\
\hline Yes & 5 & 12.2 & 36 & 87.8 & \\
\hline \multicolumn{6}{|l|}{ Breastfeeding } \\
\hline No & 9 & 31.0 & 20 & 69.0 & \multirow[t]{2}{*}{0.004} \\
\hline Yes & 1 & 2.9 & 34 & 97.1 & \\
\hline \multicolumn{6}{|l|}{ Chronic energy lack } \\
\hline Yes & 3 & 25.0 & 9 & 75.0 & \multirow[t]{2}{*}{0.381} \\
\hline No & 7 & 13.5 & 45 & 86.5 & \\
\hline \multicolumn{6}{|c|}{ Hypertension in pregnancy } \\
\hline Yes & 1 & 33.3 & 2 & 66.7 & \multirow[t]{2}{*}{0.405} \\
\hline No & 9 & 14.8 & 52 & 85.2 & \\
\hline \multicolumn{6}{|l|}{ Type of delivery } \\
\hline SC & 4 & 21.1 & 15 & 78.9 & \multirow[t]{2}{*}{0.466} \\
\hline Normal & 6 & 13.3 & 39 & 86.7 & \\
\hline Place of birth & & & & & \\
\hline Hospital & 6 & 24.0 & 19 & 76.0 & 0.170 \\
\hline Public health center & 4 & 10.3 & 35 & 89.7 & \\
\hline Stunting at 0 months & & & & & \\
\hline Yes & 2 & 50.0 & 2 & 50.0 & 0.112 \\
\hline No & 8 & 13.3 & 52 & 86.7 & \\
\hline
\end{tabular}

\section{Discussion}

In this study, the proportion of stunting at the age of 6 months was $15.6 \%$; the control group was $28.1 \%$, and the intervention group was $3.1 \%$. There were two variables related to the incidence of stunting, maternal age, and exclusive breastfeeding.

One of the maternal characteristics related to stunting was age. In this study, the majority of children who experienced stunting were mothers $>35$ years old. This finding is different from the previous studies in Africa, which stated that the nutritional needs of pregnant women, including young mothers, were greater because both the baby and the mother would need nutritional intake. If the baby's nutritional intake is not sufficient, then the baby will take reserves from the mother, and the risk of moderate malnutrition is greater in children born to mothers who give birth to married and pregnant at a young age [15], [16].

In this study, the majority of children who were breastfed had normal nutritional status. Breast milk is vital for child nutrition. Several previous studies have shown that breastfeeding is very useful in preventing stunting [17], [18], [19]. Breast milk is produced by the mother and contains the nutrients needed for the needs and development of the baby. Breast milk has high calcium content and has high bioavailability to be absorbed optimally, especially in bone formation.

Provision of intervention in counseling about the importance of breastfeeding is needed when the mother is pregnant. In this study, we provide counseling related to the importance of fulfilling nutritional needs, especially in the first 1000 days of life. Flipcharts as a communication medium for behavior change can increase the effectiveness of specific program efforts in the first 1000 days of life [20].

The nutritional content of breast milk is very dense and sufficient to meet all the nutritional needs of infants, especially in the first 6 months of life. Breast milk also contains fats and proteins that are important for the baby's growth and development of the nervous system. In addition, the antibodies in breast milk can also increase the baby's immune system so that he is not susceptible to disease [21]. Breastfeeding is the best choice because many scientific studies have shown that breastfed babies have a lower risk of stunting than those who are not breastfed [22], [23], [24].

One of the challenges in exclusive breastfeeding is the place where the mother gives birth. In many cases, mothers who gave birth in hospital through cesarean section were treated separately between mother and child, thus preventing early breastfeeding initiation. Failure to do early breastfeeding initiation is likely to cause failure to exclusively breastfeed [25], [26], [27], [28]. In this study, most children born by cesarean section and did not perform early breastfeeding initiation would experience stunting.

Midwifery care carried out by midwives is critical in preventing stunting. It is given to mothers during the reproductive period, where a midwife with full responsibility will provide comprehensive care to women starting from infancy, toddlerhood, adolescence, pregnancy, childbirth, and until menopause. One of the objectives of implementing midwifery care is to empower women by physically preparing, emotional maturity to prepare for pregnancy, maintaining health and nutrition during pregnancy, planning childbirth and breastfeeding, child care, providing balanced nutrition, and stimulating child development according to the age [29], [30].

The implementation of midwifery care is expected to contribute to creative and innovative health development, especially in realizing integrated health services. One of the expected medium-term outcomes through integrated stunting prevention interventions is a reduction in anemia in pregnant women and adolescent girls, a decrease in the incidence of lowbirth-weight infants, and an increase in the number of 
exclusive breastfeeding for infants. The achievement of this medium-term goal can be done through the provision of comprehensive midwifery care to women of reproductive age [31]. Therefore, midwifery care that is carried out correctly following the objectives is expected to be one of the efforts to prevent stunting, of course, by not neglecting other efforts and strategies.

\section{Conclusion}

Based on the results of the study, the proportion of children who experience stunting at the age of 6 months was $15.6 \%$, the proportion of children who experience stunting at the age of 6 months in the control group was $28.1 \%$ while in the intervention group only $3.1 \%$. Breastfeeding can prevent the occurrence of stunting in children. We suggest for Community Health Centres, especially village midwives, that the provision of information related to stunting, including other health problems related to maternal and child health, should be more massive. The empowerment of cadres as assistants to village midwives must be carried out to ease the work of midwives so that cadres can convey the delivery of information to pregnant women.

\section{Acknowledgment}

We thank the Head of Mapane Health Center, who has permitted us to conduct this research.

\section{References}

1. Kementerian PPN/Bappenas. Pedoman Pelaksanaan Intervensi Penurunan Stunting Terintegrasi di Kabupaten/Kota. Jakarta: Kedeputian Bidang Pembangunan Manusia, Masyarakat dan Kebudayaan Kementerian Perencanaan Pembangunan Nasional/Badan Perencanaan Pembangunan Nasional; 2018.

2. Weise AS. TARGET: $40 \%$ Reduction in the Number of Children Under-5 Who are Stunted. Geneva: World Health Organization; 2014. p. 10.

3. Development Initiatives. Global Nutrition Report 2018: Shining a Light to Spur Action on Nutrition. Bristol, UK: Development Initiatives Poverty Research Ltd.; 2018. Available from: https:// www.globalnutritionreport.org/documents/352/2018_global_ nutrition_report.pdf [Last accessed on 2021 Jul 08].

4. UNICEF, WHO, World Bank Group. Levels and Trends in Child Malnutrition 2018. New York, United States: UNICEF, WHO and the World Bank Group; 2018. Available from: https://www.who. int/nutgrowthdb/2018-jme-brochure.pdf?ua=1 [Last accessed on 2021 Apr 08].

5. Kementerian Kesehatan RI. Laporan Nasional Riskesdas
2018. Jakarta: Badan Penelitian dan Pengembangan Kesehatan; 2018.

6. Kementerian Kesehatan RI. Buku Saku Pemantauan Status Gizi Provinsi Sulawesi Tengah Tahun 2016. Jakarta: Direktorat Gizi Masyarakat Direktorat Jenderal Kesehatan Masyarakat Kementerian Kesehatan; 2017.

7. Kementerian Kesehatan RI. Buku Saku Pemantauan Status Gizi Provinsi Sulawesi Tengah Tahun 2017. Jakarta: Direktorat Gizi Masyarakat Direktorat Jenderal Kesehatan Masyarakat Kementerian Kesehatan; 2018.

8. Kementerian Kesehatan RI. Laporan Nasional Riset Kesehatan Dasar (RISKESDAS) 2013). Jakarta: Badan Penelitian dan Pengembangan Kesehatan, Kementerian Kesehatan Rl; 2013.

9. Kementerian Kesehatan RI. Laporan Nasional Riset Kesehatan Dasar 2018. Jakarta: Badan Penelitian dan Pengembangan Kesehatan, Kementerian Kesehatan RI; 2018.

10. Manafe D. Kerugian Akibat Stunting Mencapai Rp 300 Triliun; 2018. Available from: https://www.beritasatu.com/fokus/daruratstunting [Last accessed on 2019 Dec 11].

11. Tim Nasional Percepatan Penanggulangan Kemiskinan. 100 Kabupaten/Kota Prioritas untuk Intervensi Anak Kerdil (Stunting). Vol. 1. Indonesia: Sekretariat Wakil Presiden Republik Indonesia; 2017. Available from: http://www.tnp2k. go.id/images/uploads/downloads/binder_volume1.pdf [Last accessed 2020 May 11].

12. Pratami E. Konsep Kebidanan Berdasarkan Kajian Filosofi dan Sejarah. Magetan: Forum IImiah Kesehatan; 2014.

13. Yulita N, Juwita S. Analysis of the implementation of comprehensive midwifery care (continuous of care) in the city of Pekanbaru. JOMIS J Midwiferi Sci. 2019;3(2):80-3

14. Yanti. Model Asuhan Kebidanan CoC Turunkan AKI dan AKB; 2015. Available from: https://www.ugm.ac.id/id/berita/9821model-asuhan-kebidanan-coc-turunkan-aki-dan-akb [Last accessed on 2019 Dec 11].

15. Darteh EK, Acquah E, Kumi-Kyereme A. Correlates of stunting among children in Ghana. BMC Public Health. 2014;14(1):504. https://doi.org/10.1186/1471-2458-14-504

PMid:24884653

16. Delprato $M$, Akyeampong $K$. The effect of early marriage timing on women's and children's health in Sub-Saharan Africa and Southwest Asia. Ann Glob Health. 2017;83(3-4):557-567. https://doi.org/10.1016/j.aogh.2017.10.005 PMid:29221529

17. Handayani S, Kapota WN, Oktavianto E. The relationship between exclusive breastfeeding status and the incidence of stunting in toddlers aged 24-36 months in Watugajah village, Gunungkidul district. Med Respati J IIm Kesehat. 2019;14(4):287.

18. Latifah AM, Purwanti LE, Sukamto FI.The Relationship between Exclusive Breastfeeding and Stunting among Toddlers 1-5 years. Health Sci J. 2020;4(1):142.

19. Sampe SA, Toban RC, Madi MA. The Relationship between Exclusive Breastfeeding and Stunting among Toddlers. J IIm Kesehat Sandi Husada. 2020;11(1):448-55.

20. Nasrul N, Zainul Z, Hafid F, Taqwin T. Benefits of Flipchart and Banner Media in Health Behavior of 1000 Days of Life in Central Sulawesi. Med Kesehat Masy Indones. 2018;14(1):52.

21. Limbong ST. Turunkan Risiko Stunting Dengan Pemberian ASI; 2019. Available from: https://www.klikdokter.com/info-sehat/ read/3630879/turunkan-risiko-stunting-dengan-pemberian-asi [Last accessed on 2020 Dec 28].

22. Mikawati M, Lusiana $\mathrm{E}$, Hasriany $\mathrm{H}$. The relationship between exclusive breastfeeding (ASI) and mother heightwith incident rates stunting among child age 2-5 years in Barombong public health center, Gowa, Sulawesi Selatan. KnE Life Sci. 2019. Available from: https://www.knepublishing.com/index.php/ 
KnE-Life/article/view/5306 [Last accessed on 2020 Dec 28].

23. Barir B, Murti B, Pamungkasari EP. The associations between exclusive breastfeeding, complementary feeding, and the risk of stunting in children under five years of age: A path analysis evidence from Jombang East Java. J Matern Child Health. 2019;4(6):486-98.

24. Syeda B, Agho K, Wilson L, Maheshwari GK, Raza MQ. Relationship between breastfeeding duration and undernutrition conditions among children aged 0-3 Years in Pakistan. Int $J$ Pediatr Adolesc Med. 2021;8(1):10-7. https://doi.org/10.1016/j. ijpam.2020.01.006

PMid:33718571

25. Perez-Escamilla R, Maulen-Radovan I, Dewey KG. The association between cesarean delivery and breast-feeding outcomes among Mexican women. Am J Public Health. 1996;86(6):832-6. https://doi.org/10.2105/ajph.86.6.832 PMid:8659658

26. Pérez-Ríos N, Ramos-Valencia G, Ortiz AP. Cesarean delivery as a barrier for breastfeeding initiation: The Puerto Rican experience. J Hum Lact. 2008;24(3):293-302. https://doi. org/10.1177/0890334408316078

PMid:18539974

27. Prior E, Santhakumaran S, Gale C, Philipps LH, Modi N,
Hyde MJ. Breastfeeding after cesarean delivery: A systematic review and meta-analysis of world literature. Am J Clin Nutr. 2012;95(5):1113-35. https://doi.org/10.3945/ajcn.111.030254

PMid:22456657

28. Zanardo V, Pigozzo A, Wainer G, Marchesoni D, Gasparoni A, Di Fabio $\mathrm{S}$, et al. Early lactation failure and formula adoption after elective caesarean delivery: Cohort study. Arch Dis Child Fetal Neonatal Ed. 2013;98(1):F37-41. https://doi.org/10.1136/ archdischild-2011-301218

PMid:22516475

29. Bookari K, Yeatman H, Williamson M. Informing nutrition care in the antenatal period: Pregnant women's experiences and need for support. BioMed Res Int. 2017;2017:4856527. https://doi. org/10.1155/2017/485652

PMid:28890896

30. Perriman N, Davis DL, Ferguson S. What women value in the midwifery continuity of care model: A systematic review with meta-synthesis. Midwifery. 2018;62:220-9. https://doi. org/10.1016/j.midw.2018.04.011

PMid:29723790

31. World Health Organization. Nursing and Midwifery in the History of the World Health Organization 1948-2017. Geneva: World Health Organization; 2017. 